\title{
Osoba v právu z hlediska Vídeňské a Brněnské právní školy*
}

\section{A Person at Law from the Point of View of Vienna and Brno Schools of Legal Theory}

Karel Beran ${ }^{* *}$

\begin{abstract}
Abstrakt
Cílem článku je popsat prìstup cìsté právni védy k osobè jako personifikovanému souboru právních norem. $Z$ toho divvodu je tréba též vysvètlit prǐstup právního normativismu k subjektivnímu právu jako k. právní normè. Právni normativismus bývá často ztotožnován s Videňskou školou a zejména se jménem Hanse Kelsena. Proto je dalšm cílem tohoto článku ukázat, že i Brněnská škola, jmenovitě pak. František. Weyr ale zejména i prakticky neznámý český normativista Josef Slezák prinesla ke otázce osoby v právu mnoho originálnich a duiležitých poznatku.
\end{abstract}

\section{Klíčová slova}

Osoba; personiflkovaný soubor norem; bod pricítatelnosti; prámická osoba; prirrozená osoba; Brnènská prámí škola; Videňská právni škola; čistá právni věda; Kelsen; Weyr; Slezák.

\begin{abstract}
The aim of this article is to describe the approach of pure legal science to a person as a personified set of legal norms. For this reason it is essential to explain the approach of legal normativism to subjective rights as legal norms. Generally, legal normativism is identified with Vienna School of Legal Theory, particularly with Hans Kelsen. That is why this article is supposed to demonstrate that even Brno School of Legal Theory, especially František. Weyr or less famous Czech normativist Josef Slezák, made a significant contribution to the issue of a person at law.
\end{abstract}

\section{Keywords}

Person; Personified Set of Legal Norms; Point of Assignability; Legal Person; Natural Person; Brno School of Legal Theory; Vienna School of Legal Theory; Pure Legal Science; Kelsen; Weyr; Slezák.

\footnotetext{
* Tento článek byl zpracován v rámci projektu Grantové agentury ČR reg. č. 16-22016S „Právní jednání a odpovědnost právnických osob“.

** Doc. JUDr. Karel Beran, Ph.D., Katedra teorie práva a právních učení, Právnická fakulta, Univerzita Karlova, Praha / Department of Legal Theory and Legal Doctrines, Faculty of Law, Charles University, Prague, Czech Republic / E-mail: beran@prf.cuni.cz
} 


\section{Úvod}

Vídeňská a Brněnská škola tvoří dvě větve právně teoretického směru, který je obvykle označován jako ryzí nauka právní. ${ }^{1}$ Originální a podnětné výsledky, ke kterým dospěla $\mathrm{Br}$ něnská škola, však stojí mnohdy ve stínu toho, co předložila Vídeňská škola a zejména jejî hlavní protagonista, Hans Kelsen. Ne jinak je tomu i v prrípadě teoretického pojetí osoby.

Normativní pojetí osoby se však zdaleka nedočkalo takové pozornosti jako např́klad normativní pojetí státu. Jak ale uvedl František Weyr, ${ }^{2}$ problém vztahu osoby k člověku je analogický problému vztahu státu ve smyslu sociologickém ke státu ve smyslu normativním. ${ }^{3}$ Domnívám se, že poznatky ryzí nauky právní ohledně osoby mohou být aktuální i dnes.

V této souvislosti je třeba si uvědomit, že právní normativisté tvořili svá díla v době, kdy bylo pojmové vymezení osoby obsaženo v \16 ABGB, jenž stanovil, že „každý člověk má vrozená, již rozumem poznatelná práva, a nutno jej tudǐ̌ považovati za osobu. Otroctví nebo nevolnictvi a k. tomu se vątabujici výkon moci nejsou v téchto zemich dovolena."

Jestliže tak např. Hans Kelsen kritizoval pojetí osoby, podle kterého fyzická nebo právnická osoba „má“ právní povinnosti a subjektivní práva jako jejich nositel, ${ }^{4}$ mám za to, že implicitně kritizoval i pojmové vymezení osoby v $\int 16$ ABGB. A pokud je $\int 16$ ABGB předobrazem aktuálně platného a účinného $\int 19$ českého občanského zákoníku, ${ }^{5}$ může být Kelsenovo stanovisko důvodem k zamyšlení i dnes.

1 Pojmům „ryzí nauka právní“, „normativní teorie“, popř. „normativismus“ připisuji shodný význam. Jsem si vědom, že původní označení „normativní teorie“ bylo v návaznosti na Kelsena, tedy zejména v německy psané literatuře (a následně též v jejích anglických překladech), nahrazeno pojmem „ryzí nauka právní“ (Reine Rechtslehre, Pure Theory of Law). Důvod pro to spočíval kromě jiného ve zdůraznění, že jde o teorii, která se vztahuje k právu, resp. k právním normám. Ovšem vzhledem k tomu, že čeští zastánci ryzí nauky právní vesměs i nadále používali pojem „,normativní teorie“, používám těchto pojmů promiscue, nebot' se stejně jako Weyr domnívám, že ,jde konec koncui jen o poubý vnèjši problém terminologicky" K tomu srovnej WEYR, F. Teorie práva. Brno - Praha, 1936, s. 347-348.

2 WEYR, F., 1936, op. cit., s. 94.

3 „Stát ve smyslu sociologickém (přrodovédeckém) či historicko-politickém má se k pojmu státu ve smyslu normativním podobnè jako člověke ve smyslu přrrodovédeckém (biologickém) k ,osobě" ve smyslu normativnim, tj. k povinnostnimu subjektu. Praktický normotvirce je ztotožnuje, tj. prípiná ke prírodnimu faktu své normativni konstrukce, což. Znamená napr., že problašuje biologickou jednotku ,člověka" za povinnostni subjekt (právní). Tím nestávají se však oba teoreticky týmž předmětem (roz. poznávání). Nemůže tedy např. praktický normotvůrce stanoviti, kdy vzniká člověk ve smyslu biologickém, tj. svými normami snad zpưsobiti (kausálně) jeho vznik; může arcit' stanoviti, kdy vzniká „právnická osobnost“ onoho člověka, nap̌r. zásadou, že ji dlužno považovat za vzniklou okamžikem, kdy oddělí se plod od těla mateřského. Stanovením této zásady neapiusobuje ovšem vanike člověka pro obor védy prírodni (v tomto prüpadě lékařrské nebo biologické). Podobně nemüže norma - roz: právní - zpisobiti vznike státu ve smyslu sociologickém. "

4 K tomu srovnej KELSEN, H. Pure Theory of Law. California (USA): University of California Press, 1967, s. $169-172$.

5 \19 odst. 1 stanoví: „Každý člověk má vrozená, již samotným rozumem a citem poznatelná prirozená práva, a tudíz. se považuje za osobu. Zákon stanoví jen mezue uplatňování priroz̧ných práv člověka a zpuisob jejich ochrany. " 
Přístup k problému „osoby“ a zejména k řešení vztahu člověka a osoby však nebyl u Hanse Kelsena na straně jedné a Františka Weyra a Jozefa Slezáka na straně druhé stejný. Mým úmyslem je proto ukázat nejen na společná východiska, ale také na odlišnosti. Z tohoto hlediska vyčnívá zejména dílo brněnského normativisty Josefa Slezáka, jehož ambicí bylo vyřešit problém osoby jakožto bodu přičitatelnosti pomocí pojmu „,normotvorná jednotka”. Pojem „normotvorné jednotky“ měl podle Slezáka nahradit pojem subjektu práva, tedy i osoby fyzické a právnické.

Jakkoli se Slezákův nový pojem nesetkal s úspěchem, domnívám se, že jeho dílo má nesmírnou hodnotu z hlediska analýzy pojmu právního subjektu, resp. osoby. Zcela se proto shoduji s názorem J. Hurdíka, že se jedná o dílo pozoruhodné, nejen co se týká pojetí osoby jako takové, nýbrž hlavně kvůli jeho normativnímu pohledu na osobu právnickou. ${ }^{6}$ Slezákovo pojetí považuji za originální a významný př́spěvek Brněnské školy k pochopení subjektu práva. Př́spěvek, jenž by neměl upadnout do zapomenutí. Což je také jedním z hlavních cílů této statě.

\section{Kelsenovo pojetí osoby v právu}

Podle Hanse Kelsena tradiční právní věda ${ }^{7}$ ztotožňuje subjekt práva s „právní osobou“ (Rechtsperson/Legal Person). Tradiční pojetí subjektu práva přitom vychází z toho, že subjektem práva je osoba a že osobou nemůže být nikdo jiný než člověk. ${ }^{8}$ Subjekt práva je z tohoto hlediska chápán jako nositel práv a povinností, přičemž pokud je tímto nositelem člověk, pak mluvíme o fyzické osobě. Jestliže je tímto nositelem něco jiného než člověk, mluvíme o osobě právnické.

Z tohoto pohledu tak osoba představuje právní substanci, které náleží práva a povinnosti jako její právní kvalita. „Myšlenka, že „osoba má“ povinnosti a práva, tak v sobè zabrnuje vątah

6 HURDÍK, J. Př́íspěvek normativisty Josefa Slezáka k vývoji koncepce právnických osob. In: Misto normativni teorie v soudobém právním myšlení. Brno, 2003, s. 175-180.

7 Pojmu tradiční právní věda užívám ve významu, v jakém jej používali právní normativisté v situacích, kdy se proti této „tradični“ vědě vymezovali. Tímto pojmem nemá být řečeno, že se má právní nauka dělit na normativní teorii a tradiční právní vědu. $V$ takovém prrípadě by totiž mohly vzniknout pochybnosti o tom, co to vlastně je „tradiční právní věda“. Nenormativistická sféra totiž nepochybně představuje v právní teorii řadu nejrůznějších proudů od volnoprávní školy po marxismus, přičemž ani jeden z uvedených směrů není v právní teorii „tradiční“. Pojem „tradiční právní věda“, tak jak je použit a myšlen v tomto článku, má vyjádřit pouze to, že jde o všechny ostatní směry právní vědy, které nevycházejí ze striktního metodologického východiska ryzí právní nauky, kterým je odlišování toho, „co je“, od toho, co „býti má“, přičemž předmětem zkoumání ryzí právní nauky je pouze to, co „býti má“, tj. právní normy, a proto je ryzí. Zatímco všechny ostatní směry právní vědy takto striktní nejsou, a z tohoto hlediska jsou „tradični““.

8 Klasické vyjádření této myšlenky nacházíme u Savignyho, podle kterého „piovodní pojem osoby nebo práuního subjektu musi spadat v jedno s pojmem člověke a tato piovodni identita obou pojmù müže být vyjádrena následujicí formulí: každý (jednotlivý) člověke a pouze (jednotlivý) clověk je právně zpuisobily'. (SAVIGNY, F. C. System des heutigen römischen Rechts. 2 Bd. Berlin, 1840, s. 1). 
mezi substancí a kvalitou".9 Toto východisko tradiční právní vědy je však podle Kelsena nepřesné, resp. nesprávné. Právní norma totiž nemůže determinovat člověka v celé jeho existenci. Člověk může být subjektem „práva“ pouze k určitému vymezenému rozsahu jednání a zdržení se jednání. ${ }^{10}$ Tam, kde chování člověka není předmětem práv a povinností, není ani člověk v žádném vztahu k právnímu řádu. ${ }^{11}$

„Být osobou" nebo „být právnickou osobou“ je totožné s tím mit právni povinnosti a subjektivni práva. Osoba jako nositel povinnosti a práv neni ničrm odlisným od povinnosti a práv - tak jako strom, který má kmen, vètve a kvèty, neni hmotou rozdílnou od kmene, vètvi a kvètui, ale je pouze soubrnem téchto prvkù. Fyzická nebo právnická osoba, která „má“ povinnosti a práva jakožto jejich nositel, je témito povinnostmi a právy - soubrnem právnich povinnosti a práv, jejichž soubrn je prenesené vyjádřen v pojmu ,osoba “12

Chyba tradičního právního uvažování spočívá podle Kelsena v tom, že hledá vždy „něco“, tj. určitou substanci, které práva a povinnosti náležejí. Proto je také lidské chování (jako určitá kvalita) nesprávně pochopeno jako substance, tj. subjekt práv a povinnosti. ${ }^{13}$ Tato konstrukce je podle Kelsena př́značná pro primitivní mytologické uvažování, jež se vyznačuje tím, že každému objektu přiznává duši, která mu panuje (animismus).

Tak tomu ale podle něj není: „Osoba existuje pouze potud, pokud „má“ povinnosti a práva; mimo ně osoba žádnou existenci nemá. Definovat fyzickou (prirrozenou) osobu jako lidskou bytost je nesprávné, protože člověke a osoba nejsou jen dvèma rozdílnými pojmy, nýbř̃ i výsledky dvou na sobè zcela nezávislých zpuisobu chápaní. Pojem clověka vycházi z jeho biologického a fyziologickébo bytí, a proto je i pojmem prírodnich věd. Osoba je pojmem jurisprudence, právni vědy, spočivajicí v analýze právnich norem. "14

Chápeme-li fyzickou osobu pouze jako soubor právních norem, potom nemůže dávat smysl ani obvyklé tvrzení, že osobě náleží práva a povinnosti. To by totiž znamenalo, že soubor povinností a práv má povinnosti a práva. Jednalo by se tak o nesmyslnou prázdnou tautologii. ${ }^{15}$ „Že je člověk subjektem práva (subjektem práv a povinností) neznamená, jak již bylo z diraznèno, nic jiného než to, že lidské chováni je obsahem práuních povinností a práv - nic jiného než. to, že človék je osobou nebo že má osobnost. "16 Osoba tak není prrirozenou realitou, „ale právni konstrukeci vytvorenou právni védou - pomocním pojmem pro predstaveni právnè relevantních skeutečností. "17

9 KELSEN, H. General Theory of Law and State. New Brunswick (USA): Transaction Publishers, 2007, s. 93.

10 KELSEN, H., 2007, op. cit., s. 94.

11 K opačnému pojetí, které nevychází jen z vnějšího chování člověka, srovnej zejména SOBEK, T. Psychologický pozitivismus. In: Právni myšlení. Kritika moralismu. Praha: Ústav státu a práva AV ČR, 2011, s. 371.

12 „,'To be a person” or „to have a legal personality” is identical with having legal obligations and subjective rights. The person as a holder of obligations and rights is not something that is different from the obligations and rights, as whose holder the person is presented-just as a tree which is said to have a trunk, branches, and blossoms, is not a substance different from trunk, branches, and blossoms, but merely the totality of these elements.” (KELSEN, H., 1967, op. cit., s. 172).

13 KELSEN, H., 2007, op. cit., s. 93.

14 Ibid., s. 94.

15 Ibid., s. 95.

16 KELSEN, H., 1967, op. cit., s. 172.

17 Ibid., s. 174. 
Pokud je fyzická osoba pouhou konstrukcí právního myšlení, a je tak zcela odlišná od pojmu člověka v jeho fyzické existenci, potom musí být i fyzická osoba ve skutečnosti „osobou právnickou“. Z toho logicky vyplývá, že mezi fyzickou a právnickou osobou nemůže existovat zásadní koncepční rozdíl. ${ }^{18}$ Kelsenova argumentace je následující: „Jestliže v prĭpadě právnické osoby mohou být práva a povinnosti „neseny" něčm, co není člověkem, tak i trv. fyzická osoba, keterá má práva a povinnosti (a co také musi mit právnická osoba společnébo s osobou fyzickou, nebot' obè jsou ,osoby “jako „nositele" práv a povinností), nemuiže být človékem, který je v tomto prípadě „nositelem", ale něcim, co maji člověke a právnická osoba společného. “19

To, že člověk je nebo má právní osobnost, neznamená nic jiného, než že něco z jeho jednání a opomenutí tvoří nějakým způsobem obsah norem. Proto také vzhledem k rozlišování mezi člověkem a osobou není správné tvrzení, že právo opravňuje nebo zavazuje osoby. Kdo je zavázán a oprávněn, jsou lidé. Lidské chování tvoří obsah norem, a tím i obsah povinností a práv. Lidské jednání se tak podle Kelsena stává součástí obsahu normy. „Ve skutečnosti však právni osoba neni samostatným subjektem existujicim mimo své povinnosti a práva, ale je jejich personifikovanou jednotou, nebo-li-vz̧bledem k tomu, že povinnosti a práva jsou právnimi normami - personifikovanou jednotou souboru právních norem" 20

\section{Subjektivní právo jako právní norma}

Pojetí „osoby“ jako personifikace souboru právních norem může být z dnešního hlediska matoucí. Povinnosti a práva, jichž je osoba nositelem, totiž v současnosti nechápeme jako právní normy, nýbrž jako subjektivní povinnosti a práva. $\mathrm{K}$ pochopení normativní koncepce právního subjektu je naprosto nezbytné osvětlit koncepci subjektivního práva jako právní normy. To však není tak jednoduché, jak by se na první pohled mohlo zdát. Náhled ryzí nauky právní na subjektivní právo se totiž měnil stejně jako normativní nauka sama. Rozlišujeme tak dvě etapy, které odděluje Merklovo učení o stupňovité výstavbě právního řádu.

První etapu charakterizuje převážně statický postoj, při kterém se jeví právní rád jako „něco hotovébo, strnulébo, je žnezná a nemưžze znát żmèn... “21 Tuto koncepci nalézáme v ranějších dílech zakladatelů normativní teorie; u Kelsena v jeho díle Hauptprobleme der Staatsrechtslehre (Tübingen, 1911), u Weyra pak v jeho Základech filosofie právní(Brno, 1922).

$\mathrm{V}$ této etapě ještě Kelsen vyvozoval subjektivní právo z práva objektivního a spatřoval v něm subjektivní jevovou formu („Erscheinungsform “) právní normy. ${ }^{22}$ Ta pro něj představovala cosi stálého, zatímco subjektivní právo vznikalo teprve tehdy, když to připustila

\footnotetext{
18 KELSEN, H., 2007, op. cit., s. 95-96.

19 KELSEN, H., 1967, op. cit., s. 172.

20 KELSEN, H., 2007, op. cit., s. 93.

21 WEYR, F. Základy filosofie právní. Brno, 1922, s. 138.

22 KELSEN, H. Hauptprobleme der Staatsrechtslehre. Tübingen, 1911, s. 626.
} 
norma objektivního práva jako právně relevantní skutečnost. $K$ subjektivizaci právní normy v oprávnění tak mohlo dojít pouze za předpokladu, že norma vyžadovala jako podmínku pro svoji aplikaci projev vưle jednajícího - tj. např́klad žalobu. Jen tehdy mohl nastat následek předpokládaný normou (v podobě exekuce nebo trestu).

Kelsen v této době také tvrdil, že „subjektivni právo je právni pravidlo v jeho vątahu k osobě, na jejiž dispozici je učinèna závislou podminèná vìle státu k. následku bezpráví, vyslovená v právním pravidle. Mezi právnim pravidlem a subjektivním právem tak neni identita. ${ }^{23}$ Právní pravidlo je permanentní, kdežto trvání subjektivního práva je omezené. Touto dobou dokonce ani Weyr nepřipouštěl normativní konstrukci pojmu oprávnění. Subjektivní právo totiž chápal jako problém aplikace práva. Ovšem ze statického pohledu je aplikace změna, tudíž by pojem subjektivního práva přesahoval daný normativní rámec do čehosi „metanormativního". 24

Problém aplikace a intertemporality práva tak vyřešil až Merkl ve svém „ǔ̌ení o stupnovité výstavbě právního rádu " ${ }^{25}$ Principy derogace a delegace mu umožnily vidět právní rád dynamicky, tedy jako hierarchicky uspořádaný soubor norem, ve kterém stále nejrůznějšî možné normy vznikají, mění se nebo zanikají. To, co normativní teorie dříve považovala za právní skutečnost, se nyní stalo odvozenou právní normou.

V návaznosti na to přestal Kelsen ${ }^{26}$ odvozovat subjektivní právo z objektivního a právo začal chápat výhradně jako objektivní. Subjektivní právo pro něj představovalo eventuální, nikoli však vždy nezbytně nutnou podmínku pro vznik ,,individuální normy soudního rozsudku“. Projev vůle osoby byl právě onou podmínkou, bez které by rozsudek nemohl být vydán. Subjektivní právo se tak jeví jako zajištění účasti na normotvorbě vedoucí ke konkrétní normě. Proto Kelsenova koncepce umožňuje převést každé právo na právo objektivní.

Rovněž Weyr objektivizoval všechno právo. Navíc ale nahradil původní statické rozlišení objektivního a subjektivního práva rozlišením novým, dynamickým. To proti sobě klade obecné a konkrétní normy. „Subjektivní právo je tedy normou, ovšem normou konkrétní a odvozenou. “ ${ }^{27}$ Mohlo by se tak zdát, že Kelsenovo a Weyrovo chápání subjektivního práva se neliší. Ovšem určitý rozdíl zde existuje.

Výslovně na něj upozornil Jan Matějka, jenž kritizoval „blasy, které popíraji nutnost, poprǐpadè vuibec možnost konstruke subjektivního práva“.28 Tím měl na mysli zejména Kelsenovu koncepci subjektivního práva jako „konkretizaci obecné normy“. Podle Matějky totiž Kelsen

23 Ibid.

24 K tomu srovnej WEYR, F., 1922, op. cit., s. 138.

25 MERKL, A. Die Lehre von der Rechtskraft, entwickelt aus dem Rechtsbegriff. Leipzig - Wien, 1923.

26 KELSEN, H., 1967, op. cit., s. 30-54.

27 WEYR, F., 1936, op. cit., s. 171 an.

28 MATĚJKA, J. Pojem veřejnoprávní korporace. In: Sborník věd právních a státnich. Praha, 1929, s. 15. 
vycházel z nesprávného předpokladu, „̌̌e rozdil mezi subjektivním a objektivním právem tkeví stále svými kořeny v prírozenoprávním ovzduši konstruujicim vrozená, nezadatelná práva jednotlivcova, jež. maji tvoriti absolutni hranici proti positivnimu právu“."29

Tak tomu ale podle Matějky není. Když se praví, „,̌̌e subjektivni právo je »odvoẓeno« zobjektivního práva, "znamená to, že není možný vznik subjektivního práva, aniž by první bylo právo objektivní, a také, že subjektivní právo neexistuje před právem objektivním. Právo však nestačí jen poznávat, nýbrž je třeba jej i aplikovat. Podle J. Matějky tak F. Weyr správně dokazuje, „že ke celkovému poznáni právního rádu je potrébi celé rady pojmu, keteré nelze vỉbec konstruovati (definovati) normativnè, v prèdni radě pojmu subjektivního práva (opráunèni) a jeho subjektu" 30

Tomuto pojetí subjektivního práva se blíží i koncepce Jana Krčmáře. ${ }^{31}$ Podle něj je funkcí právního řádu úprava lidského soužití a ochrana důvodných zájmů jedněch proti druhým. Proto, aby bylo těchto cílů dosaženo, ukládá právní rád lidem povinnosti, když jsou naplněny určité skutkové okolnosti. V př́ípadě porušení takto uložených povinností ukládá právní pravidlo sankci. Krčmář uvádí, že „starši právnická terminologie charakterizovala toto usporádáni tak, že se priznává nositeli zájmu oprávnèni (subjektivni právo)“. Novější terminologie pak rozeznává mezi nárokem a subjektivním právem. „Nárok se priznává tomu, na koho náleží iniciativa vymoci, aby byl odčnèn nastalý již stav, príčici se práuni normè. "Subjektivní právo je tak podle Krčmáře „určeno jako situace vytvořná právnimi normami, keterá, porušili se povinnosti uložené normami, dá vaniknout nároku“"32

\section{Weyrova koncepce subjektu práva}

Jakkoli Kelsen žádá, abychom přísně odlišovali mezi „člověkem“ a „osobou“, je si zároveň vědom jisté neoddělitelnosti těchto pojmů, když ř́ká: „Fyzická (prirrozená) osoba je personifikací souboru norem, které tím, že zakládajípovinnosti a práva obsabujici chováni člověka, reguluji chováni tohoto clověka. "33 S tím souvisí i jeho úvaha, že to, co činí osobu osobou, je její „právní osobnost“. Právní osobnost (člověka) je tedy totožná s osobou. Není však ničím jiným než souborem práv a povinností, které náležejí určité osobě.

Kelsen tak na jedné straně tvrdí, že právní osobnost představuje soubor práv a povinností, tj. vychází výlučně z právního řádu jako souboru právních norem, Kelsen však zároveň také říká, že právní řád činí lidské chování obsahem povinností a práv. ${ }^{34}$ Co je tedy

29 Ibid., s. 18.

30 Ibid., s. 20.

31 KRČMÁŘ, J. Právo občanské I. Praha, 1927, s. 69 an.

32 Ibid.

33 KELSEN, H., 1967, op. cit., s. 94-95.

34 „What, now, does the statement of traditional theory mean that the legal order invests the human being, or a group of buman beings, with the quality of legal personality - with the quality of being a "person"? It means that the legal order imposes obligations upon, or confers rights to, human beings, that is, that the legal order makes human behavior the content of obligations and rights. "(KELSEN, H., 1967, op. cit., s. 172). 
právní osobnost? Je to soubor existujících povinností a práv (tedy to, co má normativně být)? Nebo lidské chování, ${ }^{35}$ (které způsobuje, že to, co má být, se fakticky stane, a tím také povinnost zanikne)?

Právě v tom, že se Kelsen zabývá faktickým chováním člověka, spatřuje Weyr náznak, že Kelsen opouští původní zásadní dualistickou koncepci mezi světem, ,jaký je“, a světem, ,jaký býti má“. Podle Weyra však v normativním světě není místo pro fyzické jednotlivce, nýbrž pouze pro normativní body prričitatelnosti. ${ }^{36}$ Proto také Weyr ${ }^{37}$ setrvává důsledně na svém rozlišení pojmu subjektu z hlediska „abstraktní normologie“ a z hlediska aplikace práva.

Podle Weyra si „Logický pojem »nositele« subjektivnich povinnosti a práv dlužno prédstavovat jako poubé abstraketum, jemuž ve vnějsím svétě nic neodpovídá a ježje jakýmsi geometrickým bodem, k. némuž vede právni rád jednotlivé povinnosti" ${ }^{38}$ Ze svrchovanosti právního řádu plyne, že za tento bod může označit cokoli. To znamená, že právní řád může spojit s kterýmkoli kusem vnějšího světa, ba i s pouhou představou něčeho, co ve vnějším světě neexistuje, s právní subjektivitou. $\mathrm{K}$ tomuto abstraktu vede právní řád jednotlivé povinnosti. Weyr, stejně jako Kelsen, vztah mezi tímto bodem a objektem jednotlivých povinností nazývá "pricitatelnosti".

Subjektem práva ve Weyrově koncepci je tak ten, kdo je povinen uskutečnit normu, tj. obsah toho, co býti má. ${ }^{39} \mathrm{Z}$ normativního hlediska musí být tento subjekt rovněž abstrakcí - bodem přičitatelnosti. „Tento povinnostni subjekt se stává v právni teorii tžv. právní (právnickou) osobou. "40 Podle Weyra si je však třeba uvědomit, že pojem osoby (persony) je ryze normativní. V reálném světě neexistují žádné osoby - ani právnické, ani fyzické.

„Normativní pojem osoby může pak pouze znamenati bud' normotviorce, nebo povinnostní subjekt." 41

35 „Only by human behavior can a right be exercised or an obligation be fulfilled or violated. Therefore it cannot be the relation to a human being which is the element that differentiates the physical or natural person from the juristic or artificial person. Therefore, too, the so-called physical person cannot - in contradistinction to the juristic person - be defined as something like a qualified human being, qualified, that is, by bolding rights and obligations.” (KELSEN, H., 1967, op. cit., s. 173).

36 Domnívám se, že Kelsenovo stanovisko je však možné vyložit i tak, že pro právnickou i fyzickou osobu musí být společné nejen to, že se jedná o umělou právní konstrukci - soubor práv a povinností, nýbrž i to, že tato práva a povinnosti nemohou být splněny jinak než lidským chováním. Proto musí jak v př́padě fyzické osoby, tak v prrípadě právnické osoby existovat vztah k lidské bytosti, která práva a povinnosti tvořící fyzickou či právnickou osobu stanoví nebo splní. Z těchto důvodů tzv. fyzická osoba také nemůže být v protikladu k právnické osobě definována jako lidská bytost kvalifikovaná tím, že je nositelem práv a povinností.

37 WEYR, F., 1936, op. cit., s. 112 an.

38 WEYR, F., 1922, op. cit., s. 173 an.

39 WEYR, F., 1936, op. cit., s. 112 an.

40 Ibid.

41 Ibid., s. 113. 
V obou prípadech jde o subjektivizaci, čili o subjektivní pojetí normy. „Na misto objektivní normy (to, co býti má) nastupuje bud' normotvirce (ten, kdo chce, ẓ̌ nèco být má), nebo povinnostní subjekt (ten, který jest povinen, odpověden za to, co má býti). ' ${ }^{42}$ Avšak předmět se nemění. Subjektivisticky konstruovaná norma (jakožto normotvorný nebo povinnostní subjekt) zůstává svou podstatou stále normou. ${ }^{43}$

K normativnímu pohledu na právní řád přispěl také Sedláček, který rozlišil pojmy čisté (formální podmínky právnického poznávánî), obsahové (obsah práva) a nově systematické (systematika právního řádu vzhledem k individuálním, morálním, hospodářským či jiným zájmům). Pojem subjektu práva tak můžeme chápat nejen čistě formálně či obsahově, ale rovněž nám může poodhalit hranice normativního systému vůči systémům jiným - coby pojem systematický. ${ }^{44}$

Proto je také podle Weyra ${ }^{45}$ pojem právní osobnosti nejen teoretickým pojmem regulativním, nýbrž i systematickým. Osoba v právu jako systematický pojem nás pak navádí $\mathrm{k}$ praktické funkci normy, která spočívá $\mathrm{v}$,jeji aplikovatelnosti ve svètě vnèjsím - povinnosti mưže mit pouze jednotlivý člověk (ale ne každý, srov. napr. šllence, nemluvñata apod.) jako fyzická jednotka biologická, protože jen on jest s to, aby si je psychologickým pochodem wvèdomil a podle nich jednal, tj. je plnil. " 46

\section{Slezákova teorie osoby jako „normotvorné jednotky“}

Osoba chápaná jako pouhý bod přičitatelnosti má však své slabiny. Především se jedná o pojem natolik široký, že pod něj lze podřadit téměř cokoli. Bodem prričitatelnosti je v tomto smyslu jak stát, tak státní úrad nebo i jednotlivec. Tato koncepce tedy vede $\mathrm{k}$ prŕlišné objektivizaci práva, která v konečném důsledku znamená, že jediným opěrným bodem je stát.

Jeli právní subjekt koncipován jako „bod přičitatelnosti“, nedají se na něm „nalézti žádné vlastnosti, které by odlisily jeden právni subjekt od jinébo, a tento pojem sám nelze jižpodradit žádnému pojmu vyššimu “ ${ }^{47} \mathrm{Z}$ praktických důvodů by však při aplikaci práva měly existovat jisté pevné opěrné body, které si osoba aplikující právo může představit bez ohledu na subjektivizaci právních norem. Z toho důvodu se pokusil Josef Slezák najít nějaký systematický

42 Ibid.

43 Z tohoto hlediska lze také pochopit normativistické ztotožnění státu s právním řádem. Vyjdemeli totiž z normativního východiska identifikace normotvorného, resp. povinnostního subjektu s právní normou, potom normativní poznávání státu musí ve skutečnosti znamenat normativní poznávání jeho právního řádu.

44 SEDLÁČEK, J. Občanské právo československé. V̌̌eobecné nauky. Brno, 1931, s. 40 an.

45 WEYR, F., 1936, op. cit., s. 114.

46 Ibid.

47 SLEZÁK, J. Normotvorná jednotka. Praha, 1947, s. 62. 
pojem v Sedláčkově smyslu, který by byl společný pro co největší počet jiných právních pojmů.

Konstatuje, že „tímto pojmem nemuiře býti právní subjekt jako bod pricitatelnosti sám, nýbř̌ že to musi býti užsi pojem, s bohatšm obsabem, jebož pojmovým znakem právni subjekt sice bude, ale nebude znakem jediným, nýbrž jednim z více znakư, z. nichž žádný nesmi býti kausálni nebo teleologické povaby “. ${ }^{48}$ Jelikož Slezák takový systematický pojem nenalézá, rozhoduje se jej definovat sám v díle, které je nazváno stejně jako pojem, jenž měl podle něj „právní subjekt“ nahradit. Tímto pojmem je „normotvorná jednotka“.

\subsection{Dynamické hledisko}

Slezák se nejprve zaměřuje na dynamické hledisko normotvorné jednotky, tj. hledisko, ze kterého se právní řád proměňuje neustálým vznikáním právních norem. Vychází přitom z toho, že „empirické generelní právni normy maji zpravidla abstraktni skutkové podstaty (...), deleguji však jiného činitele - orgán, aby, rídě se určitými pravidly, vyjádril je v konkrétnich pojmech, které jsou v rozsahu abstraktnich pojmu, užitých ve skutkových podstatách generelni normy. "49 Takto delegovaný normotvorný subjekt spojuje abstraktně vyjádřené podmínky v nový normativní obsah a dochází tu k tomu, co Slezák nazývá „konkretizační normotvorbou“.

Z perspektivy generální/delegační normy chápe konkretizaci jako skutkovou podstatu, ovšem ,ponèvadそ̌ tato podstata je i výrazem toho, co býti má, je zároveñ právni normou, keterá ov̌rem odvozuje normativni relevanci od delegačni normy". Delegační norma s abstraktní hypotézou pak musí vymezovat:

1. delegovaný normotvorný subjekt,

2. vymezeni pricitatelnosti,

3. formy normotvornébo procesu (formálni determinace),

4. kompetence normotvornébo subjektu (materiální determinace).

Jsouli dány všechny čtyři pojmové znaky, je již splněno nutné minimum pro vznik platné právní normy. Normotvornou jednotku Slezák definuje jako „soubor norem stanovicí, kterému subjektu pricítaný, a kým, jakým postupem, v jaké formě a kompetenčním rámci učinèný výraz. toho, co býti má, je právni normou. "50 Normotvornou jednotku přitom reprezentuje pŕímo její subjekt, jehož název označuje celou normotvornou jednotku se všemi jejími znaky a součástmi. Tyto znaky jsou pak ,tím více propracovány, na čím nižš́ rovině normativní relevance se vyskytuje, a tím všeobecněji vyjádřeny, čím je blǐ̌ze nejuy šsi normè. "51

\footnotetext{
48 Ibid.

49 SLEZÁK, J., 1947, op. cit., s. 64.

50 Ibid., s. 65 .

51 Ibid., s. 66.
} 
Zároveň platí, že ne všechny prvky normotvorné jednotky musí být nutně obsaženy v témže zákoně. Naopak. Jednotlivé prvky mohou být přejímány z nadřazených právních norem. V konkrétní normě, která určuje danou normotvornou jednotku, následně stačí určit subjekt a jeho kompetence. Takový subjekt pak svojí normotvorbou zakládá dílčí soubor norem, což má podle Slezáka „zulástni výz̨nam v majetkovém právu, kde je konstrukce normotvorné jednotky prostředkem, jímž právni rád poskytuje lidem majetkovou autonomii “52 Jak ale odlišit jednu určitou normotvornou jednotku od druhé? To je pro Slezáka úkolem interpretace. Obecně hovoříme o normotvorné jednotce jako o abstraktní konstrukci, která však v konkrétních př́ipadech nabývá různých podob. $\mathrm{K}$ jejich odhalení prý musíme $\mathrm{v}$ celém právním řádu nalézt ,prvkyy, keteré $k$ ni logicky patř (...), a rekonstruovat ji z. téchto prvk.ü. 53

Prvním z těchto prvků je normotvorný subjekt, ,jemuž se jako relevantni prǐrítaji myšlenkové obsaby, které konkretizuji abstraktni skutkovou podstatu delegačni normy "54 Úkolem delegační normy je tak především, aby ve své hypotéze normotvorný subjekt vymezila. Může se tak stát různými zpo̊soby. Povinný normotvorný subjekt bývá zpravidla př́mo vytvořen delegační normou (soud, úřad aj.), na rozdíl od nepovinného subjektu, jehož vznik bývá vázán na nějakou skutkovou podstatu označenou v delegační normě, a to i bez př́mého zásahu povinné normotvorby (např. narození člověka).

Obzvláště v konkrétních normách (tj. zejména smlouvách) je podle Slezáka důležité přesné označení subjektu, kterým dochází k vlastní konkretizaci normy. Vyzdvihuje zde normativní význam jména a firmy, které jsou „slovním výrazem, jimž se konkretizuje subjekt do té míry, že konkretizace precháż́ v individualizaci“. Ve všech případech však platí, že pod normotvorným subjektem se rozumí abstraktní bod přičitatelnosti v normativním slova smyslu, „který mưže norma promitnouti ve vnèjsím svètè kamkoli“.

Vzhledem k tomu, že právní subjekt představuje pouhou myšlenkovou konstrukci, je nutné, abychom mu byli schopni přičíst skutečné myšlenkové projevy. Slezák zde podobně jako Krčmář odkazuje na skutečnost, že výhradně „logický intelekt člověka je schopen synthetických úsudkư, jejichž vyjádřnim se dèje konkretisace norem " ${ }^{55}$ Většinou se tak děje tím, že se myšlenkové obsahy intelektu člověka přičítají jeho vlastnímu normotvornému subjektu, který je v právním řádu označován jako „fyzická osoba“.

Čí projevy však máme přičíst někomu, kdo je reálně nemůže mít (právnická osoba, nesvéprávný aj.)? Podle Slezáka to opět musí stanovit delegační norma. „Výslovného ustanoveni o pričcitatelnosti je treba tam, kde subjekt nebyl promitnut do psychofyzického jedince. Technicky reši empirické normy věc tak, že konstrunji tžv. orgány toho keterého normotvornébo subjektu z lidi,

\footnotetext{
52 Ibid., s. 67.

53 Ibid..

54 Ibid., s. 69.

55 Ibid..
} 
jejichそ̌projevy se subjektu pričitajį. "56 To se týká pouze všeho jednání jménem, nikoliv už jednání za normotvorný subjekt.

Dalším nezbytným prvkem normotvorné jednotky je formální determinace, kam spadá jak samotný normotvorný postup, tak forma výsledné normy. Normotvorný postup stanovuje formální předpoklady, které je třeba splnit, aby byl projev prričítaný normotvornému subjektu právně relevantní (při přijímání zákonů se bude jednat o jednací řády, při vynášení rozsudků o procesní předpisy a při uzavírání smluv o ustanovení občanského zákoníku, která se procesu uzavírání týkajî).

Forma výsledné normy je určující pro způsob, jakým má být konkretizační normotvorba zachycena. Nutno zdo̊raznit, že tato forma přitom zahrnuje jak individuální, tak normativní právní akty, tj. od ústavního zákona přes vyhlášky až např. po smlouvu. U prvotní normotvorby se jedná o ústavní či obyčejné zákony a také dekrety. U druhotné normotvorby jde o správní akty, rozsudky, rozhodčí výroky atd. A pro normotvorbu soukromého práva je typická forma smluv, závětí apod. ${ }^{57}$ Slezák se zároveň zmiňuje i o tzv. povinnostní determinaci, která se týká jen některých subjektů, tj. takových, které mají normotvorbu povinnou. Pak je logické, že musí být jasně vyjádřeny i skutečnosti, které jsou rozhodné pro vznik konkretizační normy. ${ }^{58}$

Materiální determinace, tj. vymezení kompetencí normotvorného subjektu, je poslední nutnou částí každé normotvorné jednotky. Kompetencí pak Slezák nazývá „soubrn materiálních podminek delegované normotvorby “59 Delegovaný subjekt nemá neomezenou normotvornou působnost. Zákonodárce stanovuje materiální rámec, ve kterém je myšlenkový obsah prričitatelný subjektu relevantní. Je to kompetence normotvorného subjektu, která je u každé delegované normotvorby obsahově vymezená ustanovením právního předpisu. Platí, že o čím nižší stupeň normotvorby se jedná, tím jsou kompetence subjektu užší. Kromě toho bývají normotvorné jednotky determinovány ještě dalšími obsahovými znaky - např. princip výdělečnosti u jednotky obchodní normotvorby, účel normotvorby u obchodních společností a spolků.

\subsection{Statické hledisko}

Při statickém pohledu na právní řád již nejde o to, jak vznikají normy, nýbrž o to, zda-li povinnost, která je s právní normou spojena, je platná a vynutitelná. Z tohoto úhlu pohledu popisuje Slezák normotvornou jednotku jako ,jednotku kreačnich pravidel, podminek platné normy jakožto interpretačni materiál" 60 Proto je třeba zjistit, zda jsou všechny výše

\footnotetext{
56 Ibid..

57 Ibid., s. 69-70.

58 Ibid., s. 70.

59 Ibid., s. 71.

60 Ibid., s. 72.
} 
uvedené pojmové znaky normotvorné jednotky součástí aktuálně platného právního řádu. Jestliže ano, potom má normotvorná jednotka význam především jakožto podmínka platnosti jiné právní normy.

Není možné připustit, že by existovala konkrétní norma bez normotvorné jednotky. ${ }^{61}$ Normotvorná jednotka tedy musí být dána pro každou normotvorbu: „ústavní qákon povolává parlament ke vydáváni norem ve formě zákona, občanský zákon člověke ve formè smluv, obchodní zákon kupce ke uzavíráni obchodů (...). Proto můžeme odkrýt normologickou strukturu ve všech práunich predpisech. "62

Realizace generálních (zde nikoliv dílčích) právních norem znamená konkretizaci, aplikaci a exekuci. „Soubor práunich norem, jimiž je upravena realisace generelni normy, nazveme realisačním okruhem této normy. "63 Normotvorná jednotka, která je těmito normami delegována (soudy, správní úřady), pak produkuje konkrétní normy na základě norem empirických a její normotvorba je nazvána normotvorbou aplikační. ${ }^{64}$

Normotvorná jednotka tak v této fázi aplikuje podmiňující skutkovou podstatu na kauzální stavy a děje. Touto skutkovou podstatou je hodnotí a výsledek (shodu nebo neshodu) vyjadřuje ve formě vykonatelných právních norem. Realizační okruhy mohou mít různou strukturu. Rozdíl je v tom, jestli je podmiňující skutková podstata bez delegace, anebo je taky delegační. Podle toho můžeme rozlišit normy s jednou normotvornou jednotkou a normy se dvěma normotvornými jednotkami.

U norem s jednou normotvornou jednotkou je skutková podstata vyjádřena jako nějaké konkrétní chování, které má denotát v reálném světě. Neoznačuje nějakou odvozenou normu, ale zcela jasně vykresluje, co se nepodmíněně musí stát, aby normotvorná jednotka vytvořila konkretizační normu. „Konkétni skutkové podstaty jsou tak čistými skutkovými podstatami, nikoli zároveň odvozenými normami, "65 výsledek hodnocení je vyjádřen formou druhotných norem, které konkretizují skutkové podstaty podmiňující i podmíněné a které jsou vykonatelné. ${ }^{66}$

Kategorii norem s jednou normotvornou jednotkou Slezák charakterizuje na normě trestní. Normotvornou jednotkou je zde trestní soud, který vystupuje jako „subjek.t povinnostně determinované aplikačni normotvorby". Ten konkretizuje jak podmiňující skutkovou podstatu (konkrétní trestný čin spáchaný konkrétním člověkem), tak podmíněnou

\footnotetext{
61 Z toho vyplývá jednak požadavek Grundnormy, jednak možnost nalézt pro každou existující konkrétní normu její normotvorný subjekt, který skrz normotvornou jednotku identifikuje, čí jednání se tomuto subjektu prričítá.

62 SLEZÁK, J., 1947, op. cit., s. 71-73.

63 Ibid., s. 73.

64 Ibid., s. 73-74.

65 Ibid., s. 74.

66 Ibid., s. 74-75.
} 
skutkovou podstatu (udělení konkrétního trestu) do formy konkrétního trestního rozsudku - normy. Je zde tedy př́má návaznost exekuce na aplikační normotvorbu. ${ }^{67}$

Normy se dvěma normotvornými jednotkami charakterizuje přítomnost delegační podmiňující skutkové podstaty, která se „omezuje na konstrukci normotvorné jednotky a ponechává její normotvorbè, aby v rámci delegace sama stanovila, co konkerétnè má býti, a v tomto smèru pro individuálni prípad pojmově vyjádřla konkretisaci abstraktni skutkové podstaty ve formè delegované normy ".68 Činnost takové delegované normotvorné jednotky pak můžeme nazvat konkretizační (individualizační) normotvorbou.

Dobrým příkladem této konstrukce je např. správní soud, který deleguje svůj exekuční orgán k výkonu jeho konkrétních norem. Hypotéza norem uplatňovaných zmíněným exekučním orgánem má podobu „stanovil-li soud takto“, což vyjadřuje již zmíněnou delegaci. Stejně tak můžeme uvažovat i o normách s více než dvěma normotvornými jednotkami. $V$ takovém případě mluvíme o normotvorných jednotkách druhé, třetí a další instance (napřr. soustava soudů). V̌̌dy je ovšem nutná existence konečné normotvorné jednotky (napřr. Nejvyššího soudu), která „udř̌uje veškerou normotvorbu ve státě v jednotné linii" 69

V empirických normách je bohužel skutková podstata podmiňující i podmíněná značně komplikovaně vyjádřena. Často se totiž vyskytují skutkové podstaty delegační i bez delegace vedle sebe v rámci jedné zevní jednotky. Např́klad v občanském zákoníku nalezneme v oblasti obligačního práva skutkové podstaty delegační, zatímco u práv věcných je ,pojmová kresba dosti ostrá již̃v zákonné skutkové podstatě, takž̃e neni treba jejího doplnèni néjakým dalšim myšlenkovým obsahem, aby jí bylo možné hodnotit skutečnost, "70 a tudíž jde o skutkovou podstatu bez delegace.

Na prŕkladech žaloby, smlouvy apod. se ale ukazuje, že systematický pojem normotvorné jednotky na normativní úrovni odpovídá skutečnosti. To lze dle Slezáka demonstrovat na žalobě, která je podstatná nejen jako podnět k zahájení činnosti aplikační normotvorby, nýbrž i pro konkretizaci kompetencí aplikační normotvorby pro daný případ. V aplikační normotvorbě mají totiž empirické normy i více normotvorných jednotek - tzv. instancí. Ty jsou vždy formálně i obsahově determinovány a jejich činnost je v podstatě totožná s činností aplikační normotvorby vưči normotvorbě konkretizační. ${ }^{71}$

\footnotetext{
67 Ibid., s. 75.

68 Ibid., s. 76.

69 Ibid., s. 80.

70 Ibid., s. 78.

71 Ibid., s. 79-80.
} 


\subsection{Fyzická a právnická osoba}

Poté, co Slezák vymezil pojem normotvorné jednotky z dynamického a statického pohledu, se dostává k základní otázce, kterou je postradatelnost, či nepostradatelnost pojmu osoby v právním řádu. Vychází přitom z toho, že subjektem konkretizační normotvorby je subjekt zvaný osoba, který je promítnut bud' do člověka (pak mluvíme o osobě fyzické), nebo jinam (tehdy mluvíme o osobě právnické). Na první pohled zřetelný rozdíl mezi těmito „osobami“ se podle Slezáka zmenšuje, uvažujeme-li o obou jako o normotvorných jednotkách.

Nebot' platíli u fyzické osoby, že „subjektu normotvorné jednotky se pričitaji právnè relevantní projevy myšlenkových obsabu tohoto člověkea, " tak i „projevy diskursivnich konkretisujicich myšlenkových obsahĩ (...)"skupiny lidí sdružujících se v normotvorné jednotce, jejíž subjekt není promítnut do žádného z nich, se „....) nepričitaji jim, nýbrž subjektu normotvorné jednotky, již nauka nazvala právnickou osobou “72 To nás dle Slezáka vybízí ke srovnání fyzické a právnické osoby jako dvou normotvorných jednotek lišících se pouze druhem subjektu. Jejich individualizace se děje při konkretizační normotvorbě, a to označením jména či firmy subjektu normotvorné jednotky.

Právnické osoby se však od fyzických přece jen liší. Zcela v souladu s Krčmářem zmiňuje Slezák nutnost existence orgánů právnické osoby, jejichž projevy se právnické osobě přičítají, a rovněž vylučuje z kompetence právnické osoby výkon práv rodinných, manželských apod. Další rozdíl mezi fyzickou a právnickou osobou Slezák spatřuje v tzv. majetkovém krytí normotvorby, které považuje za jeden ze způsobů, jimiž právní řád pečuje o realizaci norem.

Požadavek majetkového krytí se vyskytuje hlavně v majetkovém právu a u normotvorných jednotek, jejichž subjektům vznikají konkrétní majetkové závazky. Intenzita tohoto požadavku je v právním řádu různě odstupňována - nejmírnější je u fyzické osoby, která může disponovat svou normotvornou zpơsobilostí a duševní i tělesnou pracovní způsobilostí. ${ }^{73} \mathrm{U}$ právnické osoby se vyskytuje preventivní forma majetkového krytí normotvorby vzhledem k požadavku určitého rezervoáru hodnot, který slouží k úhradě závazků, jež vznikají její normotvorbou. Empirické normy někdy vážou vznik právnické osoby právě na tento rezervoár. ${ }^{74}$

72 Ibid., s. 81.

73 Pomocí předpisů dědického práva pečuje právní rád o to, aby byl po zániku fyzické osoby reservoár hodnot, sloužící k majetkovému krytí její normotvorby, převeden do jiných jmění.

74 Také on musí být po zániku právnické osoby převeden do jiných jmění; to upravují předpisy o likvidaci. Jmění právnické osoby bývá vytvořeno ze jmění zřizovatelů, které se po zániku právnické osoby vrací do jejich vlastnictví ve formě likvidačního podílu. 
Rozdělení právnických osob na nadace a korporace odvozuje Slezák od toho, ,jaké vztaby k hodnotám ve jmèni právnické osoby zbyly u jejích zriravatelu“ “75 Nadace je determinována nadačním účelem a její majetkové krytí je preventivní povahy, nebot’ nadační normotvorba je omezena právě a jen na nadační jmění, které už však nemá nic společného se jměním zřizovatele.

Zato jmění korporace je jměním jejích členů, kteří se většinou nevzdávají svého vztahu $\mathrm{k}$ těmto hodnotám. To se projevuje i v normotvorbě korporace. Rozlišujeme normotvorbu externí (tj. vztahy korporace k třetím osobám), která je velmi podobná normotvorbě nadace, a normotvorbu interní, která neupravuje ani tak vztahy jednotlivých členů mezi sebou, jako spíś jejich vztahy k subjektu korporace. Korporace je tedy normotvornou jednotkou s dvojí kompetencí, což, jak Slezák poukazuje, je nejviditelnější při jejím zániku, kdy je kompetence externí normotvorby determinována likvidačním účelem, a tím, jak je tento účel naplňován, se postupně zužuje. Naopak s postupující likvidací se rozšiřuje kompetence interní normotvorby k rozdělení kapitálu korporace mezi její členy.

Ze Slezákova výkladu plyne, že dosavadní pojem nejen právnické, ale i fyzické osoby lze překlenout systematickým pojmem normotvorné jednotky, která může postihnout širokou škálu právních situací, kdy si ani s jedním ze stávajících pojmů nevystačíme.

Právní řád totiž umožňuje konkretizační normotvorbu soukromého práva jako prostředek hospodářské autonomie lidí „nejen jako jedincư, nýbrž i jako skupiny jedinců, kteř̀ pro své úcely mohou použít normotvorné jednotky, jejiž subjekt neni promitnut do žádného z.nich. Zäjmy, k.teré tito jedinci sleduji prostrednictvím normotvorné jednotky, uplatnuji prakticky tím, že se stanou orgány nebo členy kolektivnich orgánu této jednotky, tak.že projevy diskursivnich konkretizujicich myšlenkových obsabu se nepričitaji jim, nýbrž subjektu normotvorné jednotky, již. nauka nazvala právnickou osobou. Prakticky provozuji jeji normotvorbu, ale závazky, které z. ni v₹niknou, se nehonoruji z jejich jmèní, núbrž ze jmèni právnické osoby. "76

Podle Slezáka je však rozdíl mezi fyzickou a nefyzickou osobou pouze minimální. „Pri úplném z̧baveni svéprávnosti člověka jsou kausálni dèje konkretisačního normotvorného procesu, jehož. výsledkem jsou konkrétni normy privìtané subjektu, promitnutému do tohoto človékea a individualisovanému v normách jeho jménem, v podstatě stejné jako analogické dèje u právnické osoby. "77 Slezák proto přichází s myšlenkou postradatelnosti pojmu právnická osoba, který mnohdy vedl k obtížím např́iklad tam, kde bylo sporné, zda se jedná o sdružení osob (societu), nebo o osobu právnickou (korporaci). Podle Slezáka si totiž „s pojmem normotvorné jednotky vystačíme u všech právních subjektư “. ${ }^{78}$

\footnotetext{
75 SLEZÁK, J., 1947, op. cit., s. 84.

76 Ibid., s. 81.

77 Ibid..

78 Ibid., s. 87.
} 


\section{Závěr}

Osoba jako právní pojem je tradičně vyvozována z člověka, at’ už jako jednotlivce nebo jako skupiny osob. Podle Hanse Kelsena však osoba existuje pouze potud, pokud „má “povinnosti a práva; mimo ně osoba žádnou existenci nemá. Za osobu v právním smyslu proto není považován člověk, nýbrž jen abstraktní „nositel“ subjektivního práva. Z této koncepce plyne i normativní konstrukce osoby, která je považována za pouhý bod, ideální, nikdy ne materiální skutečnost.

Tento bod označuje Kelsen jako „personifikaci souboru norem“, který chování člověka upravuje. Tomuto subjektu jakožto personifikaci norem však ve vnějším reálném světě nic neodpovídá. Právní řád může spojit právní subjektivitu s kterýmkoli kusem vnějšího světa, ba i s představou něčeho, co ve vnějším světě neexistuje. Vztah mezi tímto abstraktním bodem a objektem povinností se potom nazývá „přičitatelností“. Proto je také osoba v právním smyslu z normativního hlediska považována za „bod přičitatelnosti“".

Právní normativismus bývá často ztotožňován s Vídeňskou školou, především se jménem Hanse Kelsena. Cílem tohoto článku proto bylo ukázat, že i představitelé Brněnské školy, jmenovitě František Weyr a zejména pak prakticky neznámý český normativista Josef Slezák, prrinesli k otázce osoby v právu mnoho originálních a důležitých poznatků. Josef Slezák se pokusil osobu v právním smyslu analyzovat z hlediska předpokladů, které právní řád stanoví pro to, aby onen bod přičitatelnosti směl vytvořit platnou právní normu. Tento bod označil jako „normotvornou jednotku“, která znamená soubor právních norem nezbytných k tomu, aby tato jednotka mohla stanovovat ostatním subjektům právní povinnosti (včetně tzv. „konkretizační normotvorby“ zahrnující i vznik subjektivních práv). Normotvorná jednotka proto musí být k normotvorbě „delegována“ normou obsahující:

- delegovaný normotvorný subjekt,

- vymezení přičitatelnosti,

- formy normotvorného procesu (formální determinace),

- kompetence normotvorného subjektu (materiální determinace).

Výše uvedené znaky potom charakterizují každý bod přičitatelnosti, tedy každou osobu v právním smyslu. Z toho důvodu dospívá Slezák k názoru, že pojem fyzické i právnické osoby lze nahradit pojmem „,normotvorné jednotky“. Výhoda podle něj spočívá především v tom, že tento pojem lze použít i ve chvíli, kdy si nevystačíme pouze s výrazem právnická osoba. Tím má na mysli nap̌r. v té době spornou otázku právní povahy veřejné obchodní společnosti. 